Received 23.05.2016 Reviewed 29.07.2016 Accepted $\quad 02.08 .2016$

A - study design

B - data collection

C - statistical analysis

D - data interpretation

E - manuscript preparation

F - literature search

\title{
Retention capacity of extensive green roofs
}

\author{
Malgorzata SOBCZYK ${ }^{\text {BEF }}$, Maciej MROWIEC ${ }^{\text {ACD }}$
}

Częstochowa University of Technology, Faculty of Infrastructure and Environment, ul. J.H. Dąbrowskiego 69, 42-201 Częstochowa, Poland; e-mail: sobczyk.m1@wp.pl

For citation: Sobczyk M., Mrowiec M. 2016. Retention capacity of extensive green roofs. Journal of Water and Land Development. No. 30 p. 113-117. DOI: 10.1515/jwld-2016-0027.

\begin{abstract}
Climate change causes a more frequent occurrence of extreme events. The result of these phenomena is the occurrence of floods and flooding, and periods of drought. Particularly unfavorable is intensive rainfall over the urban catchments. To prevent the negative consequences of these phenomena, unconventional solutions should be used. The use of green roofs in urban areas will serve the sustainable development of cities and the impact on local ecological changes. The study was performed at two green roof platforms $1.2 \times 1.2 \times 0.1 \mathrm{~m}$ each. An analysis was performed at different intensities given for precipitation. $20 \mathrm{~min}$ for the rain to stop was observed from 68 to $100 \%$ precipitation. The study was divided into two parts. The first part of the study has been performed in the dry period. In contrast, another round of tests was repeated in other conditions after rainfall. The amount of water at two experimental green roofs platforms before the test was $11.0 \mathrm{dm}^{3}$. The research relates to the impact of green roofs on local hydrological changes. Development of technologies for green roofs had a positive impact on mitigating the effects of climate change associated with the occurrence of flooding the city.
\end{abstract}

Key words: green roofs, hydrology, urban areas

\section{INTRODUCTION}

Stormwater runoff from urban roofs makes a significant contribution to sewerage derived flooding and urban water quality problems. In most developed cities roof a account approximately $40-50 \%$ of the impermeable urban surface area. Green roofs can reduce the negative effects of stormwater in urban areas. Stormwater is retained in the green roof components where a portion of it evaporates and evapotranspirates thereby reducing stormwater volumes. The flowthrough portion is delayed in its release. Therefore, the peak flow of a rainfall event which causes sewer overflow and pollution, as well as floods, is reduced with a green roof. With reduced stormwater volumes and peak flows, the load on sewerage infrastructure is less, which can result in cost savings [BERRETTA et al. 2014; GWENDOLYN, JIM 2015; JIM 2015; VANUYTRECHT et al. 2014]. Many studies have been made to describe the positive use of the technology related to sustainable development of urban drainage systems [NAWAZ et al. 2015]. Depending on the type of green roof and the constituent layers, the average volume reduction is $78 \%$ [KÖHLER, POLL 2010]. Increasing the area of biologically open on the roofs of the buildings has a beneficial effect on air quality and the climate in cities [SCHROLL et al. 2011; STOVIN et al. 2013; Volder, DVORAK 2014]. Bearing in mind the growing popularity of green roofs is necessary to develop guidelines of their impact on sewage systems.

The importance of accurate runoff quantification cannot be overstated. Estimates of the peak rate of runoff, runoff volume, and the time distribution of flow provide the basis for all planning, design, and construction of drainage facilities. Erroneous hydrology results in infrastructure that is either undersized, oversized, or out of hydraulic balance. At the same time, it is important to understand that the result of the 
runoff analysis is an approximation. One problem at the stage of green roof design becomes determine the coefficient of runoff, which should be used in this type of roof.

The value of the runoff has a significant impact on the flow-rates adopted for dimensioning of an urban stormwater drainage system, according to the formula:

$$
Q=q \cdot F \cdot \Psi
$$

where: $Q=$ flow-rate, $\mathrm{dm}^{3} \cdot \mathrm{s}^{-1} ; q=$ rainfall intensity (calculated using IDF formula), $\mathrm{dm}^{3} \cdot \mathrm{ha}^{-1} \cdot \mathrm{s}^{-1} ; F=$ catchment area, ha; $\Psi=$ runoff coefficient.

An intensity-duration-frequency curve (IDF curve - Fig. 1) is a graphical representation of the probability that a given average rainfall intensity will occur. Rainfall intensity $\left(\mathrm{mm} \cdot \mathrm{h}^{-1}\right)$, rainfall duration (how many minutes it rained at that intensity) and rainfall frequency (how often that rain storm repeats itself) are the parameters that make up the axes of the graph of an IDF curve. An IDF curve is created with long term rainfall records collected at a rainfall monitoring station. The test results presented in the article are to investigate retention capacity extensive green roofs that have a different arrangement of layers. Until now in Poland, the Błaszczyk formula, derived originally for Warsaw and afterwards adapted for other regions, was used most frequent, due to its simplicity of the Błaszczyk equation:

$$
q=\frac{6.631 \sqrt[3]{H^{2} C^{0.33}}}{t_{d}^{0.67}}
$$

where: $H=$ depth of precipitation, $\mathrm{mm} \cdot \mathrm{y}^{-1}(H=600$ $\mathrm{mm}$ for Poland excluding mountain regions), $C=$ return period, years; $t_{d}=$ the rainfall duration, $\min$.

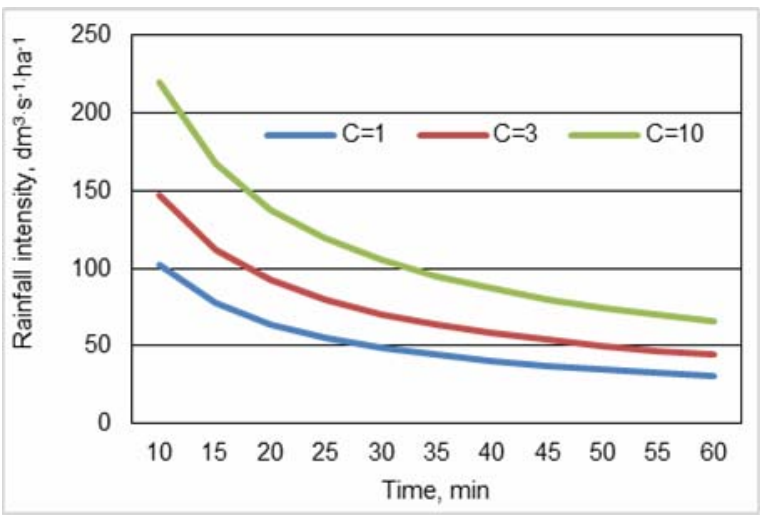

Fig. 1. Intensity-duration-frequency curves according to the Błaszczyk equation; source: own study

\section{MATERIAL AND METHODS}

The tests were performed at two experimental green roof platforms dimensions of $1.2 \times 1.2 \times 0.1 \mathrm{~m}$, which were made in June 2015 . The position number 1
(Phot. 1) consists of the following layers: a tray cultivation, absorbent protective mat SSM, non-woven filter SF, extensive substrate thickness of $8 \mathrm{~cm}$ and vegetation Sedum reflexum 'Angelina'.

The position number 2 (Phot. 2) stand is made up of such cultivation, drainage mat Bauder DSE 40 with a height of $4 \mathrm{~cm}$, non-woven filter Bauder Filtervlies 125, extensive substrate KiK Krajewscy $6 \mathrm{~cm}$ thick and vegetation Sedum floriferum Weihenstephaner Gold.

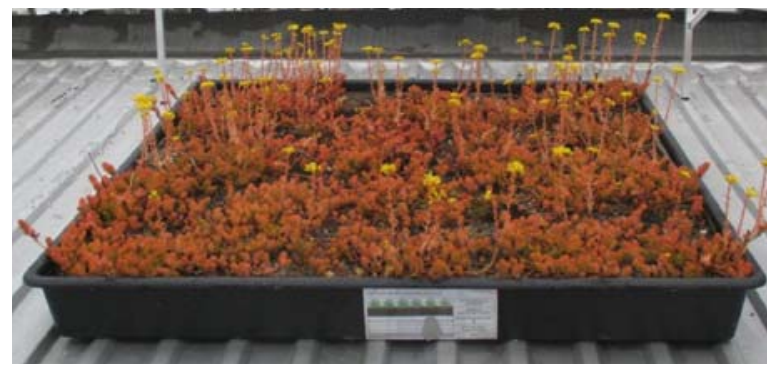

Phot. 1. Position of the experimental number 1 (photo M. Sobczyk)

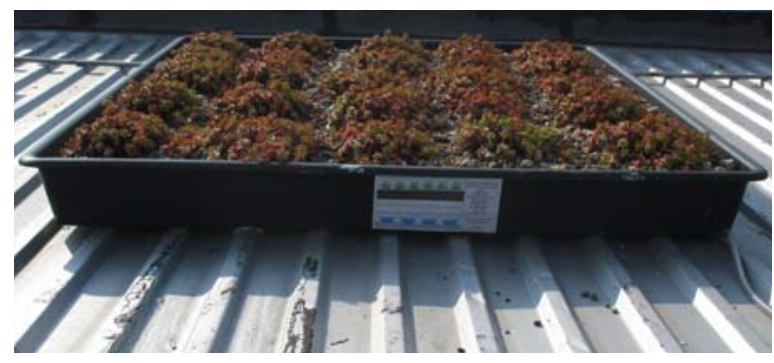

Phot. 2. Position of the experimental number 2 (photo M. Sobczyk)

Figure 2 presents diagrams of the stack positions experiments used to study the retention capacity of rainwater.

Antecedent dry weather period (ADWP) is defined as the time between the end of a precipitation event and the beginning of another. The tests considered two values of ADWP: 1 day and 5 days. Tests were carried out with a rain shower positioned over a station, through which simulated rainfall of a predetermined intensity and duration. Excess precipitation during the test as well as the outflow of the precipitation was collected in a bottle in the same interval ( 5 minutes), and then accurately measured.

Return period values used in the research were equal $C=1,3,10$ years (tab. 1). The duration of the rain used in research stems from the observation of

Table 1. Parameters of rainfalls used in the tests

\begin{tabular}{|c|c|c|c|c|}
\hline$C$ & years & 1 & 3 & 10 \\
\hline$q$ & $\mathrm{dm}^{3} \cdot \mathrm{s}^{-1} \cdot \mathrm{ha}^{-1}$ & 64.1 & 92.4 & 138.0 \\
\hline$V_{\text {dop }}$ & $\mathrm{dm}^{3}$ & 10.00 & 15.95 & 23.84 \\
\hline$Q_{\text {dop }}$ & $\mathrm{dm}^{3} \cdot \mathrm{min}^{-1}$ & 0.50 & 0.80 & 1.20 \\
\hline
\end{tabular}

Explanations: $q=$ rainfall intensity, $V_{\text {dop }}=$ total inflow volume, $Q_{\text {dop }}$ = mean inflow rate.

Source: own study. 
The scheme of the experimental number 1

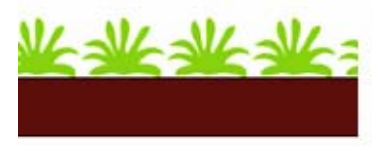

SEDUM REFLEXUM 'ANGELINA'

EXTENSIVE SUBSTRATE ZINCO

NON - WOVEN FIL TER SF

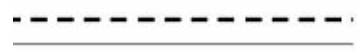

WIIIIIIIIIIIIIIIIII/

\begin{tabular}{c}
\hline ABSORBER PROTECTIVE MAT SSM \\
\hline TRAY
\end{tabular}

The scheme of the experimental number 2

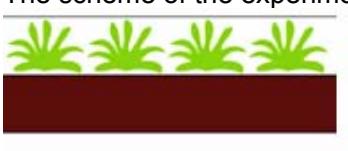

- - - - - - - - -
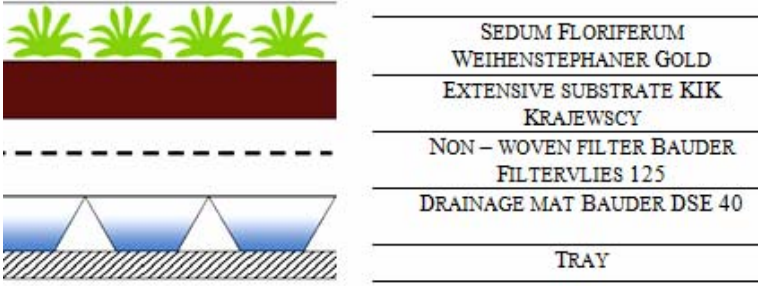

Fig. 2. Cross-section of green roofs number 1 and 2; source: own elaboration

occurrence runoff from experimental stations. Accumulated water in the layers of the arrangement, the outflow after 10 minutes in the rain. And the longer fallout would extend runoff, and thus also the size of the drain, which would not be meaningful in relation to the surface runoff. Therefore, optimally selected duration of the rain $t_{d}=20$ minutes. Below are the test results for an experiment in mini green roofs after an/the antecedent dry weather period, after precipitation and moisture of the substrate made before testing and after the test. The test cycle is divided into the study done after rainlessness and after a period of rain. It should be noted that the study after a period of rain, the day before the test rainwater retention capacity of the two positions (the whole area) were hydrated at volume of $11.0 \mathrm{dm}^{3}$.

The results for the two experimental stations showed very different retention capacities of extensive green roofs. The position number 1 store from $98 \%$ ( $C=10$ years $)$ to $100 \%(C=1$ year $)$ of total rainfall depending on the amount of rainwater falling on the surface position. The obtained volume reduction for ADWP = 1 was similar for both testing installations (from $97.75 \%$ to $100 \%$ ). These results indicate that the calculation of sewerage systems could be suggested the use of runoff coefficient values in the range $0.0-0.05$. which corresponds to the values adopted in standard calculations for parks, gardens and green areas.

Table 2. The results of flow and volume reduction to the position number 1 and 2

\begin{tabular}{|c|c|c|c|c|c|c|}
\hline \multirow{2}{*}{ Parameter } & \multicolumn{3}{|c|}{ Position number 1} & \multicolumn{3}{|c|}{ Position number 2} \\
\hline & $C=1$ & $C=3$ & $C=10$ & $C=1$ & $C=3$ & $C=10$ \\
\hline \multicolumn{7}{|c|}{ ADWP $=5$} \\
\hline Outflow flow rate, $\mathrm{dm}^{3} \cdot \mathrm{min}^{-1}$ & 0.00 & 0.06 & 0.12 & 0.06 & 0.22 & 0.40 \\
\hline Flow-rate reduction, $\%$ & 100 & 92.5 & 90.0 & 88.0 & 72.5 & 66.7 \\
\hline Outflow volume, $\mathrm{dm}^{3}$ & 0.00 & 0.25 & 0.40 & 0.30 & 1.80 & 4.60 \\
\hline Volume reduction, $\%$ & 100 & 98.4 & 98.4 & 97.3 & 88.3 & 81.2 \\
\hline \multicolumn{7}{|c|}{$\mathbf{A D W P}=1$} \\
\hline Outflow flow rate, $\mathrm{dm}^{3} \cdot \mathrm{min}^{-1}$ & 0.00 & 0.05 & 0.10 & 0.08 & 0.24 & 0.62 \\
\hline Flow-rate reduction, $\%$ & 100 & 93.8 & 91.6 & 84.0 & 70.0 & 48.3 \\
\hline Outflow volume, $\mathrm{dm}^{3}$ & 0.00 & 0.30 & 0.55 & 0.50 & 2.05 & 7.60 \\
\hline Volume reduction, $\%$ & 100 & 98.3 & 97.7 & 95.42 & 86.6 & 68.8 \\
\hline
\end{tabular}

Source: own study.

Substrate moisture to the position number 1 variant $\mathrm{ADWP}=5$ measured prior to the test is in the range 2 to $6 \%$ after the test, while increasing the range of 8 to $11 \%$. In a variant of ADWP $=1$ it was respectively $4.5-7.5 \%$ before the test and $8.5-14 \%$ after its completion. The final moisture value to a small degree is dependent on the amount of precipitation.

The second experiment structure was characterized by significantly more variable in terms of reducing the drain. In tests carried out for $\mathrm{ADWP}=5$, the retained volume was equal to $81.1 \%$ ( $C=10$ years $)$ to $97.2 \%(C=1$ year $)$. In the case of research for ADWP $=1$ a significantly lower volume of water was retained by the green roof: $68.8 \%$ for $C=10$ years and $86 \%$ for $C=3$ years. Only $C=1$ year values for both embodiments are similar (95-97\%). In this construction, the adoption of a green roof runoff coefficient is much more problematic, since its value depends on the parameters of the precipitation, which is used in the calculation. Only for $C=1$ year it is possible to assume $\Psi=0.05$. For larger rainfall intensities, the key is to answer the question of whether you should take into account the conditions that occurred in the period before the rainfall occurs (antecedent dry weather periods). Bearing in mind that engineering calculations should be characterized by a high degree of reliability, it is more rational is to assume more unfavorable conditions (tab. 2). Under this assumption, runoff coefficient for site 2 can be estimated as $\Psi=0.31$ for $C=10$ years, $\Psi=0.14$ for $C=3$ years, and $\Psi=0.05$ for $C=1$ year. These values should be regarded as an approximation because in real conditions, the volume of runoff is influenced by a variety of factors: air temperature and moisture, wind speed, solar exposition. Considering the factors that may affect the final results, it is necessary to conduct further research to assess the impact of green roofs to relieve the municipal drainage systems. 
Figure 3 shows an example of the outflow hydrograph from position number 1 for precipitation of the return period of $C=3$ years. Maximum outflow of rainwater was reached at $25 \mathrm{~min}$ duration of the rain, and then gradually disappears after the precipitation. Retention of the rainwater tested in various climatic conditions allows one to observe the potential of green roofs. It should be noted that the positions of the experiment were on the roof of the building by which climatic conditions have a significant impact on results. Under the conditions of the Mediterranean in many publications can be seen the positive impact of green roofs on the retention of rainwater and reducing the volume of runoff [FIORETTI et al. 2012; PALLA et al. 2008; 2010]. Analysis of the British climatic conditions confirms delay runoff from the roof and reduces peak runoff. Can to retain $50.2 \%$ of the annual precipitation, as well as the retention of $30 \%$ of the volume at a higher rainfall [STOVIN et al. 2012].

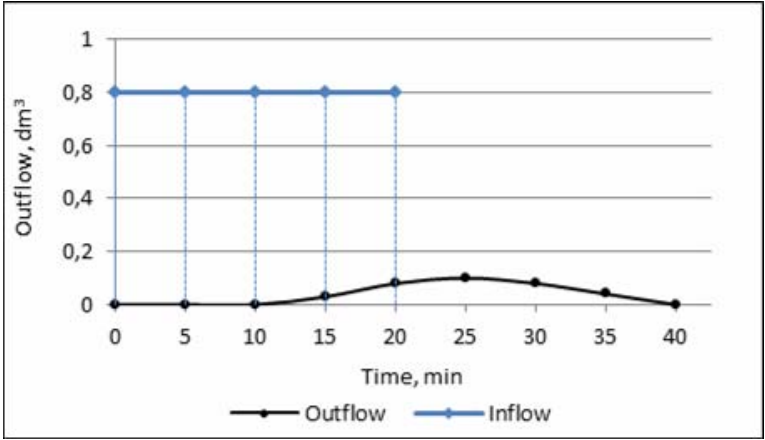

Fig. 3. Hydrograph of the outflow rainwater for position 1, $C=3$ (the precipitation); source: own study

Substrate moisture to the treatment no 2 variant ADWP $=5$ measured before the test was in the range of $1-4 \%$ and the assay increased to $4-7 \%$. In a variant of ADWP $=1$ it was respectively $2.5-5.5 \%$ before the test and $6-11 \%$ after its completion.

\section{CONCLUSIONS}

The study shows that there is a reduction of discharged rainwater from extensive green roofs. It should be noted that the thickness of the substrate starting from $6 \mathrm{~cm}$ enables the storage of the location of the precipitation. Values of the runoff coefficient calculated on the basis of measurements have shown a wide variation depending on the design of the roof. Studies have confirmed that at the stage of hydraulic calculations, the sewerage system should take into account the variability of the runoff coefficient depending on the parameters adopted to precipitation. It is necessary to conduct further investigations, which take into account other structures such as green roofs as well as an analysis of the impact of decline in the roof of its retention capacity. The above-presented results confirm the reduction of storm water runoff from applied surfaces taking into account the green roofs.
Acknowledgements

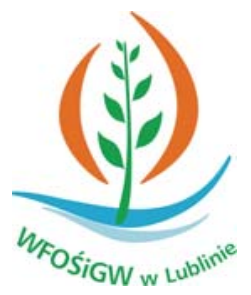

Dofinansowano ze środków

Wojewódzkiego Funduszu

Ochrony Środowiska

i Gospodarki Wodnej w Lublinie

Cofinanced by Voivodeship Fund

for Environmental Protection and Water Management in Lublin

\section{REFERENCES}

Berretta Ch., Poë S., Stovin V. 2014. Moisture content behaviour in extensive green roofs during dry periods: The influence of vegetation and substrate characteristics. Journal of Hydrology. Vol. 511 p. 374-386.

Fioretti R., PAlla A., LANZA L.G., PrinCiPI P. 2010. Green roof energy and water related performance in the Mediterranean climate. Building and Environment. No. 45 p. 1890-1904.

GWENDOLYN K.L., JiM C.Y. 2015. Identifying keystone meteorological factors of green-roof stormwater retention to inform design and planning. Landscape and Urban Planning. Vol. 143 p. 173-182.

JIM C.Y. 2015. Assessing climate-adaptation effect of extensive green roofs in cites. Landscape and Urban Planning. Vol. 138 p. $54-70$.

KÖHLER M., POLL H.P. 2010. Long-term performance of selected old Berlin greenroofs in comparison to younger extensive greenroofs in Berlin. Ecological Engineering. No. 36 p. $722-729$.

Nawaz R., McDonald A., Postoyko S. 2015. Hydrological performance of a full-scale extensive green roof located a temperate climate. Ecological Engineering. No. 82 p. $66-80$.

Palla A., GNeCCo I., LANZA L.G. 2010. Hydrologic restoration in the urban environment using green roofs. Water. No. 2 p. $140-154$.

Palla A., LanZa L.G., La Barbera P. 2008. A green roof experimental site in the Mediterranean climate. In: Proceedings of the 11th International Conference on Urban Drainage. Edinburgh, Scotland, UK p. 1-10.

Schroll E., Lambrinos J., Righetti T., SAndrock D. 2011. The role of vegetation in regulating stormwater runoff from green roofs in a winter rainfall climate. Ecological Engineering. No. 37 p. 595-600.

StOvin V., PoË S., BerRetTA CH. 2013. A modelling study of long term green roof retention performance. Journal of Environmental Management. No. 131 p. 206-215.

Stovin V., Vesuviano G., Kasmin H. 2012. The hydrological performance of a green roof test bed under UK climatic conditions. Journal of Hydrology. Vol. 414-415 p. $148-161$.

Vanuytrecht E., Mechelen Van C., Meerbeek Van K., Willems P., Hermy M., Raes D. 2014. Runoff and vegetation stress of green roofs under different climate change scenarios. Landscape and Urban Planning. No. 122 p. $68-77$.

VOLDER A., DVORAK B. 2014. Event size, substrat water content and vegetation affect storm water retention efficiency of an un-irrigated extensive green roof system in Central Texas. Sustainable Cities and Society. Vol. 10 p. 59-64. 


\section{Malgorzata SOBCZYK, Maciej MROWIEC}

\section{Pojemność retencyjna ekstensywnych zielonych dachów}

\section{STRESZCZENIE}

Zmiany klimatyczne powodują coraz częstsze występowanie zjawisk ekstremalnych. Szczególnie niekorzystne ze względów hydrologicznych jest występowanie na terenach zurbanizowanych gwałtownych burz czy też długotrwałych opadów. Skutkiem tych zjawisk jest występowanie powodzi czy podtopień. Nadmierne uszczelnienie obszarów miejskich powoduje podczas nawalnego deszczu podtopienie terenu związane z niewydolnym systemem kanalizacyjnym. Z kolei długotrwałe okresy bezdeszczowe powodują susze. Aby zapobiegać u źródła negatywnym następstwom tych zjawisk należy stosować niekonwencjonalne rozwiązania. Wprowadzenie zielonych dachów na terenach zurbanizowanych będzie służyło zrównoważonemu rozwojowi miast oraz pozytywnie wpłynie na lokalne zmiany ekologiczne. Ekstensywne zielone dachy to konstrukcje składające się z warstwy drenażowej, filtracyjnej, substratu i roślinności. Struktura zielonych dachów ma wpływ na ilość zgromadzonej wody deszczowej we wszystkich warstwach w trakcie opadu. W przypadku nawalnych deszczów taki dach może zatrzymać czasowo pierwszą fale deszczu. W zależności od zastosowanego rodzaju dachu - ekstensywnego bądź intensywnego woda deszczowa może zostać zmagazynowana nawet w całości. W sytuacji niedoboru opadów $\mathrm{w}$ przyrodzie zgromadzona woda $\mathrm{w}$ warstwach zielonego dachu będzie zasilała rośliny oraz poprawi wilgotność powietrza. Badania wykonano na dwóch stanowiskach doświadczalnych o wymiarach $1,2 \times 1,2 \times 0,1 \mathrm{~m}$ każde. Analizy przeprowadzono, przyjmując różną intensywność opadu. W przypadku deszczu trwającego 20 min zaobserwowano zatrzymanie od $68 \%$ do $100 \%$ opadu. Badania były podzielone na dwie części. Pierwsza część badań została wykonana w okresie bezdeszczowym, natomiast kolejną turę badań wykonano w innych warunkach, po opadzie deszczu. Ilość zgromadzonej wody na stanowisku przed badaniem wynosiła $11,0 \mathrm{dm}^{3}$. Prace badawcze dotyczą wpływu zielonych dachów na lokalne zmiany hydrologiczne. Konstrukcja zielonych dachów jest rozwiązaniem, które umożliwia zagospodarowanie wód opadowych w obrębie nieruchomości oraz ogranicza odprowadzenie ich do kanalizacji deszczowej. Tym samym stosowanie takiego budownictwa będzie łagodzić skutki występowania gwałtownych czy długotrwałych opadów na terenach zurbanizowanych, których następstwem są podtopienia miejskie.

Slowa kluczowe: hydrologia, tereny zurbanizowane, zielone dachy 